Pengaruh Kualitas Pelayanan Terhadap Kepuasan Nasabah Pada Bank Rakyat Indonesia

Cabang Adisucipto Yogyakarta

\title{
Pengaruh Kualitas Pelayanan Terhadap Kepuasan Nasabah Pada Bank Rakyat Indonesia Cabang Adisucipto Yogyakarta
}

\author{
Hakim $^{1}$ Selamat Muliadi ${ }^{2}$ \\ Universitas Nahdlatul Ulama Al-Ghazali Cilacap ${ }^{1}$ \\ Sekolah Tinggi Ekonomi Islam (STEI) HAMZAR ${ }^{2}$
}

$\triangle$ Corresponding Author:

Nama Penulis: Hakim

E-mail: mazmurakim@yahoo.com

\begin{abstract}
:
Service quality is a fundamental factor in a company engaged in the service sector, in this case BRI Branch Adisucipto Yogyakarta. Customer satisfaction can be seen from each level of service provided massively. From this research, the conclusion is that the customers of BRI Adisucipto Yogyakarta Branch are quite satisfied with the services provided, but there are several things that are important and need to be considered such as the Tangibles variable because physical evidence is abstract and must be felt directly by the customer. Tangibles quality of service, including adequate physical appearance of the room (waiting room, seating, comfortable interior), parking for service counters and electronic and communication infrastructure must be available so that the customer does not become difficult if the customer wants to connect with the Bank through the telephone network.
\end{abstract}

Keywords : Service Quality, Customer Satisfaction, BRI Adisucipto Yogyakarta

\begin{abstract}
Abstrak:
Kualitas ibidang jasa, dalam hal ini adalah BRI Cabang Adisucipto Yogyakarta. Kepuasan pelayanan merupakan faktor yang fundamental dalam sebuah perusahaan yang bergeraka $d$ nasabah bisa dilihat dari seberapa besar tingkat layanan jasa yang diberikan secara masif. Dari hasil penelitian ini menyimpulkan nasabah BRI Cabang Adisucipto Yogyakarta cukup puas terhadap pelayanan yang diberikan, namun ada beberapa hal yang penting dan perlu diperhatikan seperti pada variabel Tangibles karena bukti pisik sifatnya abstrak dan harus dirasakan langsung oleh nasabah. Kualitas pelayanan yang sifatnya Tangibles, meliputi penampilan fisik ruangan yang memadai (ruangan tunggu, tempat duduk, interior yang nyaman), parkir loket pelayanan dan prasarana elektronik dan komonikasi harus tersedia cukup sehingga nsabah tidak menjadi kesulitan jika nasabah ingin berhubungan dengan Bank melaluni jaringan telepon.
\end{abstract}

Kata Kunci : Kualitas Pelayanan, Kepuasan Nasabah, BRI Adisucipto Yogyakarta 
Pengaruh Kualitas Pelayanan Terhadap Kepuasan Nasabah Pada Bank Rakyat Indonesia Cabang Adisucipto Yogyakarta

\section{PENDAHULUAN}

Kualitas pelayanan yang baik akan menentukan sikap konsumen dalam menilai, memutuskan sekaligus memberikan kesan terhadap pelayanan yang diberikan, karena sering kali konsumen yang merasa puas akan cendrung lebih loyal terhadap perusahaan itu. Kepuasan konsumen terhadap pelayanan perusahaan di pasar akan menjadi sangat penting untuk mempertahankan posisi perusahaan di pasar serta menciptakan efektifitas dan efisensi perusahaan. Kualitas pelayanan perusahaan-perusahaan itu dimaksudkan sebagai usaha untuk memenuhi harapan konsumen, sedangkan harapan konsumen tidak selamanya sama. Seiring dengan berjalannya waktu, harapan konsumen terhadap kualitas pelayanan akan berbeda dan terus akan berkembang. Kualitas merupakan suatu kondisi dinamis yang berhubungan dengan produk, jasa, manusia, proses, dan lingkungan yang memenuhi atau melibihi harapan (Tjiptono, 2004: 123).

Kualitas pelayanan yang baik merupakan upaya yang dapat digunakan oleh perusahaan untuk menghadapi persaingan dalam bidang jasa yang erat kaitannya dengan kepuasan pelanggan. Kualitas pelayanan yang diharapkan oleh para konsumen adalah fasilitas yang memadai, pelayanan yang baik, kenyamanan, keamanan, ketenangan dan hasil yang memuaskan sehingga pihak manajemen harus memikirkan kualitas pelayanan bank. Upaya peningkatan mutu pelayanan di bank, akan sangat efektif apabila peningkatan mutu pelayanan merupakan tujuan sehari-hari dari seluruh karyawan bank, mulai dari pimpinan puncak atau direktur sampai dengan para pelaksana pelayanan bank.

BRI Cabang Adisucipto Yogyakarta, merupakan sebuah perusahaan yang menyediakan produk skaligus layanan (service) secara langsung kepada maasyarakat di daerah Adisucipto Yogyakarta. Keberhasilan suatu perusahaan yang bergerak dibidang jasa dipengaruhi oleh bagaimana perusahaan tersebut mampu membahagiakan pelanggan dengan pelayanan yang dberikan, sehingga akan tercipta kepuasan nasabah. Sedangkan menurut Zeithmal, et al. (Tjiptono 
Pengaruh Kualitas Pelayanan Terhadap Kepuasan Nasabah Pada Bank Rakyat Indonesia Cabang Adisucipto Yogyakarta dan Candra, 2007: 156) kepuasan nasabah akan tercapai apabila kualitas jasa yang diberikan meliputi 5 (lima) dimensi kualitas pelayanan meliputi: Tangibel, Reliability, Responsiveness, Assurance, Emphaty

Kualitas pelayanan berkaitan erat dengan kepuasan pelanggan, kepuasan adalah merupakan perbedaan antara harapan dan unjuk kerja. Apabila harapan tinggi sementara unjuk kerjanya biasa-biasa saja, kepuasan tidak akan tercapai (sangat mungkin konsumen akan merasa kecewa), sebaliknya apabila unjuk kerjanya melebihi dari yang diharapkan kepuasan akan menjadi meningkat.

Saat ini banyak pemakai jasa Bank BRI Cabang Adisucipto Yogyakarta semakin kritis terhadap pelayanan yang diberikan, hal ini disebabkan karena banyaknya bank-bank yang tersedia dan dapat memberikan banyak pilihan bagi mereka. Tujuan penelitian ini adalah untuk mengetahui pengaruh kualitas layanan yang terdiri dari Tangibles, Reliability, Responsiveness, Assurance, dan Emphaty secara parsial dan simultan terhadap kepuasan Nasabah Bank BRI Cabang Adisucipto Yogyakarta.

Hipotesis penelitiannya adalah Ada pengaruh secara persial (individu) dan simultan (bersama sama) dalam dimensi penampilan fisik Tangibel (X1), Reliability (X2), Responsiveness (X3), Assurance (X4), dan Empathy (X5) terhadap kepuasan nasabah Bank BRI Cabang Adisucipto Yogyakarta.

\section{METODE PENELITIAN}

Populasi adalah wilayah generalisasi yang terdiri atas : obyek/subyek yang mempunyai kualitas dan karakteristik tertentu yang ditetapkan oleh peneliti untuk dipelajari dan kemudian ditarik kesimpulannya (Sugiono, 2011: 61). Dalam penelitian ini yang menjadi populasinya adalah seluruh nasabah yang menggunakan jasa pelayanan Bank BRI Cabang Adisucipto Yogyakarta.

Sampel yang diambil adalah para nasabah pemegang tabungan yang menggunakan jasa Bank Rakyat Indonesia Cabang Adisucipto Yogyakarta berjumlah 100 orang. Untuk metode pengumpulan data menggunakan kuisioner. Alat analisis menggunakan regresi liner berganda. 
Pengaruh Kualitas Pelayanan Terhadap Kepuasan Nasabah Pada Bank Rakyat Indonesia Cabang Adisucipto Yogyakarta

$\mathrm{Y}=\mathrm{a}+\mathrm{b}_{1} \mathrm{X}_{1}+\mathrm{b}_{2} \mathrm{X}_{2}+\mathrm{b}_{3} \mathrm{X}_{3}+\mathrm{b}_{4} \mathrm{X}_{4}+\mathrm{b}_{5} \mathrm{X}_{5}+\mathrm{e}$

Dimana:

$\mathrm{Y}=$ Variabel dependen yaitu kepuasan nasabah

$X_{1=}$ Bukti langsung (Tangibles)

$X_{2}=$ Keandalan (Reliability)

$X_{3}=$ daya tanggap (Responsiveness)

$X_{4}=$ jaminan (Assurance)

$X_{5}=($ Emphaty $)$

$a=$ konstanta

$e=$ kesalahan eror

$b_{1}, b_{2}, b_{3}, b_{4}, b_{5}=$ koefisien-koefisien regresi

\section{Hasil Penelitian}

Tabel 1

Analisis Regresi Liner Berganda

\begin{tabular}{|c|c|c|c|c|c|c|}
\hline \multicolumn{7}{|c|}{ Coefficients $^{a}$} \\
\hline \multirow{2}{*}{\multicolumn{2}{|c|}{ Model }} & \multicolumn{2}{|c|}{ Unstandardized Coefficients } & $\begin{array}{l}\text { Standardized } \\
\text { Coefficients }\end{array}$ & \multirow[b]{2}{*}{$\mathrm{T}$} & \multirow[b]{2}{*}{ Sig. } \\
\hline & & B & Std. Error & Beta & & \\
\hline \multirow[t]{6}{*}{1} & (Constant) & 6.852 & 2.397 & & 2.859 & .005 \\
\hline & Tangible & .312 & .139 & .191 & 2.241 & .027 \\
\hline & Reliability & .344 & .167 & .235 & 2.062 & .042 \\
\hline & responsiveness & .141 & .223 & .095 & .634 & .528 \\
\hline & Assurance & .032 & .259 & .016 & .123 & .902 \\
\hline & Emapty & .503 & .171 & .318 & 2.948 & .004 \\
\hline
\end{tabular}

a. Dependent Variable: kepuasan

Dari tabel 2.13 diperoleh persamaan liner berganda sebagai berikut:

$$
Y=6,852+0,312 X_{1}+0,344 X_{2}+0,141 X_{3}+0,032 X_{4}+0,503 X_{5}
$$


Pengaruh Kualitas Pelayanan Terhadap Kepuasan Nasabah Pada Bank Rakyat Indonesia Cabang Adisucipto Yogyakarta

Tabel 2

Uji hipotesis secara simultan

ANOVA $^{b}$

\begin{tabular}{|c|l|l|l|l|l|}
\hline \multicolumn{1}{|c|}{ Model } & \multicolumn{1}{|c|}{$\begin{array}{c}\text { Sum of } \\
\text { Squares }\end{array}$} & Df & Mean Square & \multicolumn{1}{c|}{ F } & \multicolumn{1}{c|}{ Sig. } \\
\hline 1 Regression & 599.231 & 5 & 119.846 & 17.157 & $.000^{\mathrm{a}}$ \\
Residual & 656.609 & 94 & 6.985 & & \\
Total & 1255.840 & 99 & & & \\
\hline
\end{tabular}

a. Predictors: (Constant), emapty, tangible, reliability, assurance, responsiveness

b. Dependent Variable: kepuasan

Berdasarkan dari hasil pengujian diperoleh nilai $F_{\text {hitung }}$ sebesar 17.157 dan F tabel sebesar 2,47 dengan signifikansi sebesar 0,000. Oleh karena $F_{\text {hitung }}>F_{\text {tabel }}(17.157>2,47)$ dengan nilai signifikansi lebih kecil dari 0,05 (sig < 0,05), dengan demikian hipotesis yang menyatakan "terdapat pengaruh yang signifikan secara bersama-sama variabel bukti langsung (Tangibles), kehandalan (Reliability), daya tanggap (Responsiveness), jaminan (Assurance) dan empaty (Emphaty) terhadap kepuasan nasabah di Bank BRI Cabang Adisucipto Yogyakarta,

\section{PEMBAHASAN}

Dalam Rangka menghadapi persaingan yang semakin ketat terutama dengan Bank-bank lainnya yang semakin hari mulai bermunculan, sebaiknya Bank BRI Cabang Adisucipto Yogyakarta dimana yang kan datang harus selalu berusaha meningkatkan pelayananya terutama yang bersifat Responsiveness dan Assurance.

Kedua variabel ini tidak berpengaruh namun Bank BRI sehingga memberikan kontribusi yang relatif sedikit terhadap kepuasan nasabah pada Bank BRI Cabang Adisucipto Yogyakarta dibandingkan faktor-faktor yang lain sedangkan dalam dunia perbankan Responsiveness (daya tanggap) dan Assurance (jaminan) merupakan salah satu faktor penting yang diperlukan untuk memberikan pelayanan yang cepat dan perasaan aman kepada nasabah. Oleh karena itu, Bank BRI Cabang Adisucipto Yogyakarta perlu meningkatkan 
Pengaruh Kualitas Pelayanan Terhadap Kepuasan Nasabah Pada Bank Rakyat Indonesia Cabang Adisucipto Yogyakarta mutu pelayanan yang bersifat Responsiveneess dan Assurance. Responsiveness antara lain meliputi bersedia membantu kesulitan yang dihadapi oleh nasabah, siap, sigap dan ramah dalam melayani nasabah, memberikan kecepatan dalam menanggapi permintaan nasabah, dan memberikan pelayanan yang cepat dan tepat kepada nasabah. Tidak berpengaruhnya variabel ini karena daya tanggap nasabah sudah bagus dan untuk pencairan kredit relatif mudah bisa cair dalam satu hari apabila prosedurnya sudah lengkap atau terpenuhi.

sedangkan Assurance meliputi memberikan keamanan dalam hal transaksi, memberikan pelayanan secara tuntas dan tegas terhadap para nasabahnya, memiliki kecepatan dalam memperoses pengiriman uang/jasa lainnya, maupun dalam hal palayanan nasabah secara langsung dan memberikan palayanan transaksi dengan jaminan kebenaran. Tidak berpengaruhnya variabel ini karena nasabah sudah yakin bahwa prosedur sudah benar sesuai regulasi yang berlaku sehingga nasabah menjadi tidak ragu lagi untuk menjadi nasabah BRI cabang Adisucipto Yogyakarta. Selain itu Bank BRI adalah bank milik pemerintah (BUMN) artinya tingkat risiko relatif sedikit dibandingkan dengan bank-bank lain dalam hal jaminan keamanan.

\section{KESIMPULAN}

Terdapat pengaruh yang signifikan antara mutu pelayanan yang besifat Tangibles terhadap kepusan nasabah Bank BRI cabang Adisucipto Yogyakarta.

Terdapat pengaruh yang signifikan antara mutu pelayanan yang besifat Reliability terhadap kepuasan nasabah pada Bank BRI cabang Adisucipto Yogyakarta.

Tidak terdapat pengaruh yang signifikan antara mutu pelayanan yang besifat Responsiveness terhadap kepuasan nasabah pada Bank BRI cabang Adisucipto Yogyakarta.

Tidak terdapat pengaruh yang signifikan antara mutu pelayanan yang besifat Assurance terhadap kepuasan nasabah pada Bank BRI cabang Adisucipto Yogyakarta. 
Pengaruh Kualitas Pelayanan Terhadap Kepuasan Nasabah Pada Bank Rakyat Indonesia Cabang Adisucipto Yogyakarta

\section{DAFTAR PUSTAKA}

Aksa H, Mastuti dan Ratnasari Tri Ririn. 2004. Manajemen Pemasaran Jasa Teori dan Kasus. Surabaya: Ghalia Indonesia Anggota IKAPI

Consuelo G. Sevilla, Iesus A. Ochave. 1993. Pengantar Metode Penilitian. Terjemahan Alimuddin Tuwu. Jakarta: Universitas Indonesia.

Ghozali Imam. 2006. Aplikasi Analisis Multivariate Dengan Program SPSS. Cetakan Keempat, Semarang: Universitas Diponogoro.

Hasan M ikbal. 2001. Pokok-Pokok Materi Statistik 2 (statistik inferensif) Edisi kedua. Jakarta: Bumi Aksara.

http : //ejournal.unud.ac.id/abstrak/yuliarmi(1).pdf

Indriantoro Nur dan Bambang Supomo. 1999. Metodologi Penelitian Bisnis Untuk Akutansi dan Manajemen. Edisi Pertama. Yogyakarta: BPFE

Kotler Philip. 1999. Manajemen Pemasaran. Edisi melenium pertama. Jakarta: Prentice

Kasmir. 2003. Bank dan Lembaga Keuangan Lainnya. Edisi Revisi. Cetakan Ketujuh. Jakarta: PT Raja Grafindo Persada

Lupiyoadi Rambat. 2001. manajemen pemasaran jasa teori dan praktek. Edisi pertama. Jakarta: Salemba Empat

Sugiyono. 2011. Statistik Untuk Penelitian. Bandung: Alfabeta

Sugiyono. 2008. Statistika Untuk penelitian, cetakan ketiga belas. Bandung: CV Alfabeta.

Sujarweni V. Wiratna, 2007. Belajar Mudah SPSS untuk Penelitian. Yogyakarta: Global Media Informasi

Sujarweni V. Wiratna, 2007. Panduan Mudah Menggunakan SPSS dan Contoh Penelitian Bidang Ekonomi. Yogyakarta : Ardana Media Tjiptono. 2006. Manajmen Jasa, yogyakarta: Andi Publiser Usmara. A. 2003. Strategi Baru Manejmen Pemasaan. Yogyakarta: Amara Books. 